\title{
Концептуальні положення реалізації соціально-гуманістичних засад адаптивної фізичної культури в українському освітньому просторі
}

\author{
Ірина Когут, Сергій Матвєєв, Вікторія Маринич, \\ Євген Гончаренко
}

Національний університет фізичного виховання і спорту України, Київ, Україна

Анотація. Результати аналізу літературних джерел свідчать про недостатню увагу науковців до питань гуманізації освіти у сфері фізичної культури і спорту. Поодинокі праці окремих фрахівців сфери не вирішують нагальні проблеми у зазначеному напрямі. Саме тому постає необхідність систематизації наявних педагогічних положень у гуманізації освіти. Мета. Визначення концептуальних положень реалізації соціально-гуманістичних засад адаптивної фрізичної культури в українському освітньому просторі. Методи. Аналіз, синтез, абстрагування, узагальнення; порівняння та аналогія; опитування і спостереження; математична статистика. Результати. На основі аналізу фахової літератури, досвіду практичної діяльност та результатів експертного опитування конкретизовано основні педагогічні умови, виконання яких забезпечить впровадження гуманістичних засад в освітній процес. Експертами запропоновано найбільш інформативні критерії ефективності гуманістично орієнтованої діяльності педагогів у закладах вищої освіти. Окреслено етапи і заходи фформування гуманістично орієнтованих спеціалістів сфери: зміна співвідношення між існуючими структурами управління освітнім процесом, формами та змістом професійної підготовки кадрів; розробка моделі професійно важливих якостей гуманістично орієнтованих фахівців. У результаті впровадження концептуальних положень реалізації соціально-гуманістичних засад адаптивної фрізичної культури в освітній процес НУФВСУ відбулися зміни у структурі та змісті професійної підготовки студентів. Впроваджені структурні перетворення забезпечують підвищення рівня професійної підготовки спеціалістів шляхом фрормування необхідних компетентностей; соціально-гуманістичних цінностей; просесійно значущих рис особистост для успішного вирішення завдань сфери фізичної культури і спорту.

Ключові слова: адаптивна фізична культура, соціально-гуманістичні засади, освіта

\section{Iryna Kohut, Serhii Matveiev, Viktoria Marynych, levhen Honcharenko}

\section{CONCEPTUAL PROVISIONS OF REALIZING SOCIO-HUMANISTIC PRINCIPLES OF ADAPTIVE PHYSICAL CULTURE IN UKRAINIAN EDUCATIONAL SPACE}

Abstract. The results of literature source analysis indicate the lack of attention of scientists to the humanization of education in the field of physical culture and sports. Single works of individual specialists in the field do not solve urgent problems in this direction. That is why there is a need to systematize the existing pedagogical provisions in the humanization of education. Objective. Determining the conceptual provisions of the implementation of socio-humanistic principles of adaptive physical culture in the Ukrainian educational space. Methods. Analysis, synthesis, abstraction, generalization; comparison and analogy; surveys and observations; mathematical statistics. Results. Based on the analysis of professional literature, practical experience and the results of the expert survey, the main pedagogical conditions are specified, the implementation of which will ensure the introduction of humanistic principles in the educational process. The experts proposed the most informative criteria for the effectiveness of humanistically oriented activities of higher education institution teachers. The stages and measures of formation of humanistically oriented specialists of the sphere are outlined: change of the relation between the existing structures of management of educational process, forms and the content of professional training of personnel; development of a model of professionally important qualities of humanistically
Когут I, Матвєєв С, Маринич В, Гончаренко $€$. Концептуальні положення реалізації соціально-гуманістичних засад адаптивної фізичної культури в українському освітньому просторі. Теорія і методика фрізичного виховання і спорту. 2020; $2: 130-142$

DOI: 10.32652/tmfvs.2020.2.130-142
Вступ. Становлення України як демократичної держави потребує реформування всіх напрямів життєдіяльності громадян і чинить суттєвий методологічний вплив на освіту. Водночас освіта впливає на суспільство, пришвидшуючи (чи сповільнюючи) його розвиток. Перед сучасною українською освітою постає завдання не лише адаптуватися до змін, що відбуваються на міжнародному та національному рівнях, а й стати надійним підґрунтям самоствердження України як демократичної, самобутньої, сильної, гуманістично орієнтованої держави [17].

Результати аналізу основних програмних документів з розвитку вітчизняної освіти дозволяють констатувати, що майбутнє освіти держава розглядає, насамперед, у їі конкурентоспроможності і якості, оптимальному співвідношенні витрат, інвестиційній привабливості тощо. Безумовно, вирішення цих проблем вкрай важливе і для суспільства в цілому. Враховуючи ієрархію цілей, для кожного індивіда, більшості соціальних інститутів найголовнішим стратегічним завданням освіти є розвиток особистості, зокрема ії гуманістичної складової, а всі інші виступають лише засобами для досягнення першорядної мети. Кардинальним напрямом змін у сучасній освіті $€$ формування особистості, здатної в конкретних соціальноекономічних умовах удосконалювати суспільне життя і себе самого.

Гуманізація є одним із провідних чинників розвитку української освіти і має на меті фрормування дбайливого ставлення до особистості, її здоров'я та стосунків з іншими [1, 9, 11, 12, 22]. Вітчизняні законодавці прагнуть створити реальну модель розвитку освітньої системи, що ґрунтується на гуманістичних засадах та спрямована на формування всебічно розвинутої осо- 
oriented specialists. Introduction of conceptual provisions for the implementation of socio-humanistic principles of adaptive physical culture in the educational process of NUPESU resulted in changes in the structure and content of professional training of students. Implemented structural transformations provide an increase in the level of professional training of specialists by forming the necessary competencies; socio-humanistic values; professionally significant personality traits for the successful solution of tasks in the field of physical culture and sport.

Keywords: adaptive physical culture, socio-humanistic bases, education.

бистості, якій притаманний високий рівень розвитку морально-етичних якостей. У Законі України «Про освіту» визначено необхідність реформування національної освіти на засадах гуманізму на всіх етапах їі розвитку. У зв'язку з цим пріоритетним напрямом досліджень $€$ соціально-педагогічні аспекти гуманізації освітнього процесу, зокрема сфрери фрізичної культури і спорту.

Аналіз літературних джерел свідчить про недостатню увагу науковців до проблеми гуманізації освіти у сфері фрізичної культури і спорту. Поодинокі праці окремих фахівців ссрери фрізичної культури не вирішують нагальні проблеми у зазначеному напрямі [7, 13-15, 21]. Саме тому постає питання про необхідність систематизації наявних педагогічних положень гуманізації освіти, що, у свою чергу, стане основою для визначення концептуальних засад створення гуманістично орієнтованого освітнього процесу під час підготовки срахівців сфери фізичної культури та спорту.

Отже, для якісного функціонування сорери фрізичної культури і спорту взагалі, та того її напряму, що передбачає роботу з особами 3 інвалідністю, враховуючи сучасні тенденції розвитку суспільства, науки та практики в організації освітнього процесу у закладах вищої освіти (3В0), слід враховуватити, що від сучасного спеціаліста вищої кваліфікації вимагається наявність ряду нових якостей в його науковій, педагогічній та виробничій діяльності, яка пов'язана з набуттям системних, комплексних знань та вміння використовувати їх у своїй спеціальності і в організації різноманітних соціальних відносин, що й обумовлює необхідність здійснення комплексного наукового дослідження у напрямі визначення ключових положень реалізації гуманістично орієнтованих засад в освітньому процесі під час підго- товки фрахівців сфрери фрізичної культури і спорту.

Дослідження виконано відповідно до плану наукової роботи Національного університету фрізичного виховання і спорту України на 2016-2020 рр. за темою 1.7 «Організаційно-методичні основи розвитку адаптивного спорту» (номер держреєстрації 0116U001613)

Мета дослідження - визначення концептуальних положень реалізації соціально-гуманістичних засад адаптивної фрізичної культури в українському освітньому просторі.

Методи дослідження: аналіз, синтез, абстрагування, узагальнення; порівняння та аналогія; індукція, дедукція; аналіз друкованих та електронних джерел інформації; системний підхід і структурно-фрункціональний аналіз; опитування і спостереження; математична статистика.

Результати дослідження та їх обговорення. У нашому дослідженні метод експертних оцінок використано для виявлення думок експертів про концептуальні положення реалізації соціально-гуманістичних засад адаптивної фрізичної культури в українському освітньому просторі. Експертиза передбачала з'ясування думок кваліфрікованих спеціалістів (20 осіб). Групу експертів становили фрахівці у сфрері фрізичного виховання і спорту, що працюють у ЗВО України: доктори наук, професори - 13 осіб, кандидати наук, доценти - 7 осіб. У дослідженнях використано метод переваги (ранжування), коли експерти оцінюють об'єкти за рангами у порядку зниження їх значущості. Чим більше балів набирає об'єкт, тим вище місце він займає і тим більш значущим він $€$.

у сучасному суспільстві змінюється уявлення про те, яким має бути освіта в XXI ст., які знання слід мати сучасній освіченій людині. У світі відбувається процес гуманізації освіти. Вища педагогічна освіта потребує підвищення рівня фрундаментальної за- гальногуманітарної ціннісної бази, розробки принципів побудови цілісного освітнього простору закладу освіти, орієнтованого на становлення особистості студента. Визначальними соціальними завданнями реформи освіти, що забезпечують належний рівень професійної підготовки майбутніх фахівців сфери фрізичної культури та спорту у роботі з особами з інвалідністю, є фрормування системи цінностей, духовного та діяльнісного підґрунтя в людині, гуманізація її свідомості, зміна ментальності суспільства. 3В0, як світові, так і вітчизняні, різними шляхами та в різні історичні періоди прагнуть реалізувати ці завдання $[4,5,8,16,18]$

У межах нашого дослідження зроблено спробу розробити механізм побудови гуманістично орієнтованого освітнього процесу в 3ВО. Першим кроком стало з'ясування на основі аналізу фахової літератури, досвіду практичної діяльності та результатів експертного опитування необхідних педагогічних умов, виконання яких забезпечить впровадження гуманістичних засад в освітній процес:

- позитивне морально-психологічне освітнє середовище, взаємна вимогливість науково-педагогічних працівників та студентів;

- підвищення гуманістичної спрямованості освітнього процесу, використовуючи традиційні та інноваційні методи, засоби, форми організації занять, аудиторну і самостійну роботу, курсові та дипломні проєкти; проходження практики в структурах, що розвивають фрізкультурно-оздоровчий і спортивний рух осіб з інвалідністю;

- розвиток когнітивного й креативного потенціалу, формування загальнолюдських цінностей у студентів (милосердя, чуйність, доброта, вміння радіти за друзів тощо);

- побудова толерантних взаємин студентів на основі формування конструктивних міжособистісних стосунків завдяки досвіду спілкування з особами $з$ інвалідністю;

- персоніфікований підхід у формуванні морально-етичних якостей студентів, що ґрунтується на збереженні прагнення бути самим собою та здібностях мати і висловлювати 


\begin{tabular}{|c|c|c|c|}
\hline & \multicolumn{2}{|r|}{ Заходи } & \multirow[b]{2}{*}{1} \\
\hline 1 & 1 & 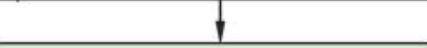 & \\
\hline Нормативні & Загальнопедагогічні & Професійно-педагогічні & Соціальні \\
\hline $\begin{array}{l}\text { - змістовна та інноваційна } \\
\text { готовність до гуманістично } \\
\text { орієнтованої діяльності; } \\
\text { - установка на розвиток } \\
\text { індивідуально- } \\
\text { психологічних морально- } \\
\text { етичних якостей у нових } \\
\text { соціальних умовах; } \\
\text { - індивідуальний підхід } \\
\text { до формування } \\
\text { соціально значущих } \\
\text { гуманістичних якостей }\end{array}$ & $\begin{array}{l}\text { - забезпечення інтегративної } \\
\text { цінності процесу професійної } \\
\text { підготовки викладачів 3ВО; } \\
\text { - актуалізація можливостей } \\
\text { ЗВО для створення } \\
\text { гуманістично орієнтованої } \\
\text { професійної компетентності } \\
\text { педагогів з урахуванням іхніх } \\
\text { особистісних та соціально } \\
\text { значущих мотиваційно- } \\
\text { ціннісних орієнтирів; } \\
\text { - стимулювання процесу } \\
\text { самовдосконалення студентів } \\
\text { та педагогів }\end{array}$ & $\begin{array}{l}\text { - наявність компетентних } \\
\text { гуманістично орієнтованих } \\
\text { педагогічних дій у професійній } \\
\text { підготовці майбутніх педагогів; } \\
\text { - співвідношення відповідних } \\
\text { методів і форм іх підготовки } \\
\text { для роботи у 3ВО; } \\
\text { - толерантні відносини між } \\
\text { студентами і викладачами; } \\
\text { - використання науково } \\
\text { обгрунтованих гуманістично } \\
\text { орієнтованих інноваційних форм } \\
\text { і методів організації роботи } \\
\text { студентів на навчальних заняттях }\end{array}$ & $\begin{array}{l}\text { - потреба в професійно- } \\
\text { компетентних, гуманістично } \\
\text { орієнтованих педагогах, } \\
\text { здатних забезпечити } \\
\text { реалізацію освітніх завдань; } \\
\text { - престижність наявності } \\
\text { загальнолюдських якостей } \\
\text { у студентів ЗВО; } \\
\text { - орієнтація на формування } \\
\text { гуманістично орієнтованого } \\
\text { способу життя студентів }\end{array}$ \\
\hline
\end{tabular}

Рисунок 1- Комплекс методичних заходів, які забезпечують досягнення студентами належного рівня розвитку загальнолюдських моральних якостей

власні судження, думки, погляди, ідеї тощо.

На думку експертів, вирішальними педагогічними умовами впровадження гуманістичних засад в освітній процес $€$ розвиток когнітивного й креативного потенціалу, формування загальнолюдських цінностей у студентів та позитивне морально-психологічне освітнє середовище, взаємна вимогливість науково-педагогічних працівників та студентів.

Гальмувати реалізацію гуманістичних засад в освітньому процесі спроможні існуючі в педагогічній діяльності перешкоди, найбільш значущими серед яких експерти виокремили рівень підготовки науково-педагогічних працівників до впровадження гуманістичних засад в освітній процес та недооцінку значущості загальнолюдських цінностей як змістової та цільової домінанти гуманізації освітнього процесу.

Створення гуманістично орієнтованого освітнього процесу у ЗВО є педагогічною стратегією, спрямованою на досягнення цілісності, узгодженості, взаєморозуміння в діяльності викладачів та студентів у формуванні загальнолюдських цінностей. Випускники освітнього закладу повинні не лише володіти знаннями, а й активно і творчо їх використовувати. Їм необхідно оволодіти не тільки методами і засобами постійного їх оновлення, але й умінням долати застарілі шаблони і стереотипи мислення і дій. Пріоритетом гуманізації освіти є загальнорозвиваючий ефрект, вдосконалення психічного і фрізичного здоров'я учасників освітнього процесу.

Метою вищої освіти є формування високого рівня індивідуальної культури, особистісних і професійних якостей випускників, що діагностовано як кінцевий результат роботи закладу вищої освіти. Водночас повинні бути створені умови для оволодіння студентами професійними вміннями та навичками, розвитку потенційних здібностей, інтелекту, формування мотивації, спрямованої на саморозвиток, самовдосконалення і самоствердження а також для фрормування системи моральних світоглядних цінностей $[3,10]$.

Із цільовими установками гуманізації освіти тісно пов'язані принципи гуманізації педагогічного процесу. Аналізуючи існуючі принципи [2, 19], експертам було запропоновано основні 3 них, що мають місце й у фізкультурній освіті. Серед провідних принципів гуманізації освітнього процесу експерти виділяють свідомість, активність і вмотивованість студентів на оволодіння навичками толерантних взаємостосунків; цілеспрямованість виховних дій на формування гуманістичного підґрунтя розвитку особистості та орієнтація на загальнолюдські цінності. Важливим, на думку експертів, $є$ також створення в педагогічному процесі простору для прояву індивідуальності та активізації самостійної і суспільно-корисної роботи.

На основі проведеного аналізу сучасного стану навчання та виховання у ЗВО розроблено педагогічні умови, що дозволяють підвищити ефективність фрормування гуманістичної свідомості студентів. Ці умови визначаються як комплекс методичних заходів, що забезпечують досягнення студентами високого (достатнього) рівня розвитку загальнолюдських моральних якостей (рис. 1).

Варто зазначити, що під час формування гуманістично орієнтованого способу життя студентів можна використовувати різні моделі його становлення. Зокрема, когнітивна модель передбачає передачу інформації про морально-етичні цінності, здоровий морально-психологічний та фрізичний стан людини, методи його регулювання, причини і наслідки асоціальної поведінки. Педагогічна модель розглядає формування гуманістично орієнтованого способу життя студентів як процес педагогічної корекції особистості суб'єкта освіти та навчання їх свідомих умінь і навичок. Соціальна модель розглядає гуманістично орієнтований спосіб життя як результат впливу середовища на існування людини. 
Проведені дослідження дозволили визначити етапи фрормування гуманістично орієнтованих фрахівців сфрери фрізичної культури і спорту, що передбачають таку послідовність їх реалізації: інсрормаційний, науково-методичний, діяльнісний, аналітико-корективний і самостійно-творчий (табл. 1).

Аналіз літературних джерел та результати експертних оцінок дозволили виділити критерії ефективності гуманістично орієнтованої роботи педагогів у ЗВО (рис. 2).
Експертами визначено найбільш впливові критерії ефективності гуманістично орієнтованої роботи педагогів у 3В0, врахування яких сприятиме не лише покращенню якості освітнього процесу, а й формуванню особистості з високим рівнем розвитку морально-етичних принципів поведінки. Найбільш значущими критеріями ефективності гуманістично орієнтованої діяльності педагогів у ЗВ0, на думку експертів, вважаються ціннісно-мотиваційний та когнітивний, за допомогою яких можна оцінити важливість розуміння фахівцями власного обов'язку формувати гуманістично орієнтовану особистість 3 високим рівнем освіченості та мотивації до сприйняття загальнолюдських цінностей для їх впровадження у подальшому житті. Визначальне місце експерти відводять креативному та мобілізаційно-діяльнісному критеріям, які підвищують значущість інноваційних форм, методів і засобів перебудови освітнього про-

\section{Т а б л и ц я 1. Етапи формування гуманістично орієнтованих фахівців сфери фізичної культури і спорту}

\begin{tabular}{|l|l|}
\hline \multicolumn{1}{|c|}{ Етап } & \multicolumn{1}{c|}{ Характеристика } \\
\hline İнформаційний & $\begin{array}{l}\text { Впровадження професійної орієнтації та мотивації, професійного образу фахівця. Відповідно кожне заняття } \\
\text { має стати для студента творчою лабораторією, нести достатній обсяг когнітивної інформації, сприяти зро- } \\
\text { станню його морально-етичних якостей }\end{array}$ \\
\hline Науково-методичний & $\begin{array}{l}\text { Формування гуманістично орієнтованої професійної компетентності шляхом оволодіння психолого- } \\
\text { педагогічними знаннями і методологією наукової діяльності; теорією і методикою викладання спеціальних } \\
\text { знань, що забезпечують набуття базового рівня професійної компетентності. Протягом цього етапу } \\
\text { відбувається формування професійної компетентності студентів (професійні знання, вміння, навички, прийо- } \\
\text { ми самоосвіти) на семінарах, «круглих столах», конференціях тощо }\end{array}$ \\
\hline Діяльнісний & $\begin{array}{l}\text { Набуття гуманістично орієнтованої професійної компетентності студентами у процесі безпосередньої } \\
\text { практичної діяльності, зокрема, волонтерської, а також уміння її творчо застосовувати, пропонуючи різні } \\
\text { технології, виявляючи оригінальність, нестандартні прийоми вирішення освітніх завдань }\end{array}$ \\
\hline Аналітико-корективнийй & $\begin{array}{l}\text { Включає аналіз і корекцію реалізації гуманістично орієнтованої професійної компетентності студентів у } \\
\text { навчально-пізнавальну та практичну діяльність, зміну індивідуального стилю роботи через співвідношення } \\
\text { об'єктивних вимог до професійної діяльності з особистісним розвитком фахівця }\end{array}$ \\
\hline Самостійно-творчий & $\begin{array}{l}\text { Спрямований на виявлення та демонстрацію рівня гуманістично орієнтованої професійної компетентності та } \\
\text { особистісної готовності студентів у практичній діяльності, а також самоосвіту і самовиховання особистості }\end{array}$ \\
\hline
\end{tabular}

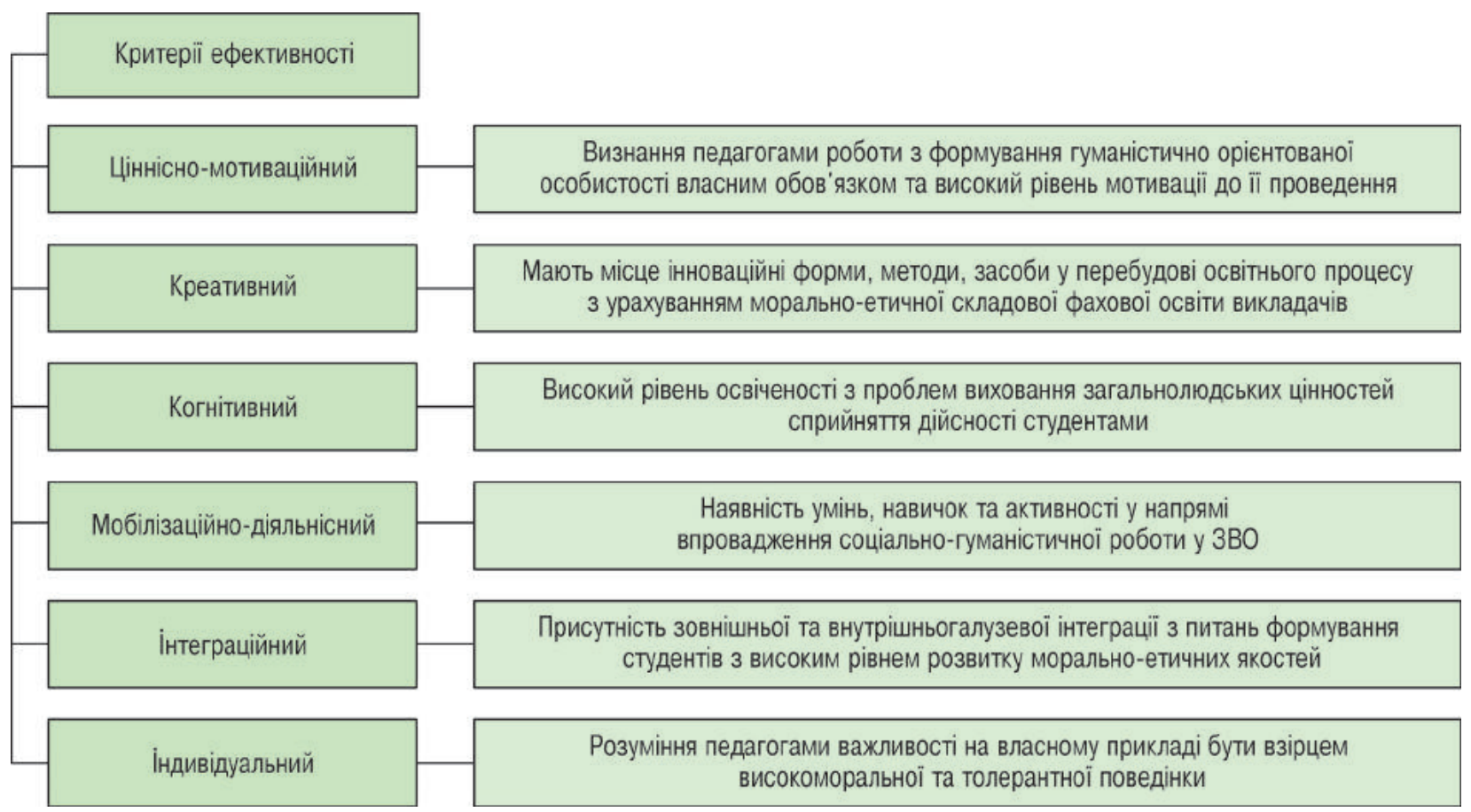

Рисунок 2 - Критерії ефрективності гуманістично орієнтованої роботи педагогів у закладах вищої освіти 


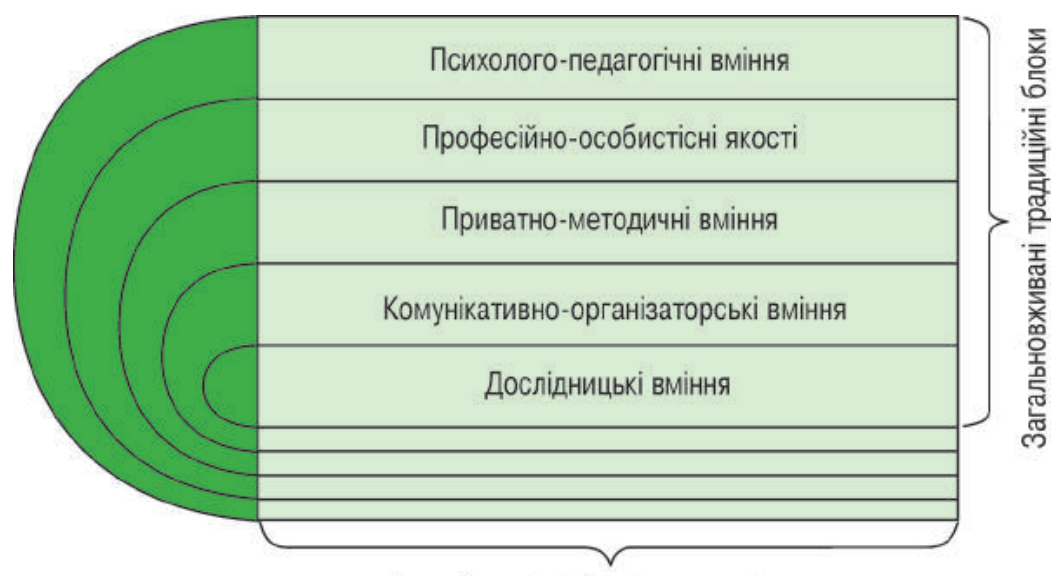

Гуманістично орієнтоване наповнення

Рисунок 3 - Основні складові професіограми спеціаліста сфрери фрізичної культури і спорту

цесу з урахуванням морально-етичної складової фрахового рівня викладачів, наявність у них умінь, навичок та наполегливості у впровадженні соціально-гуманістичної діяльності у 3B0.

За всіх часів однією 3 важливих умов удосконалення освіти було створення еталона, зразка, моделі викладача, в якій представлено основні якості особистості та перелік кваліфікаційних характеристик 3 позиції вимог, що висуваються до нього: знань, умінь, навичок, здібностей, психофізіологічних можливостей, рівня підготовки тощо. Одним із варіантів вирішення зазначеного питання стало створення професіограми.

Перші професіограми для викладачів (перелік обов'язкових якостей) було сформовано у 1920-1930-ті роки. У професіограмах викладачів за соціалістичного устрою суспільства, за винятком таких якостей, як «комуністичні переконання», «знання і вміння застосовувати методи комуністичного виховання», “систематичне підвищення ідейно-політичного рівня» тощо, знаходилися ті самі вимоги до професії педагога, що існують і сьогодні. Професіограма є засобом моніторингу якості професійної підготовки викладача до педагогічної діяльності, дозволяє спроектувати особистісне та профресійне вдосконалення педагога будь-якої спеціальності.

Профресіограма спеціаліста сорери фрізичної культури і спорту містить не лише загальні риси, типо- ві для педагогічної професії взагалі, а й специфічні - для діяльності фахівця зазначеної галузі. Вона включає характеристику головних педагогічних функцій спеціаліста сфери фрізичної культури і спорту, його особистісних якостей, загальнопедагогічних та профресійно-методичних вмінь і навичок, що забезпечують їх реалізацію.

Отже, на основі аналізу спеціальної літератури що стосується професійних компетенцій спеціаліста сфери фрізичної культури і спорту [6], сформовано його професіограму, що складається 3 п'яти основних блоків (рис. 3).

Психолого-педагогічні вміння вимагають здатності аналізувати фрахову літературу 3 фрізичного виховання та спорту; спроможність аналізувати педагогічні явища у процесі занять фізичною культурою і проводити самоаналіз своєї професійної діяльності; можливість співчувати, розуміти емоційний стан учнів та студентів, володіти майстерністю до самоорганізації.

Професійно-особистісні якості характеризуються самокритичністю, працьовитістю, старанністю, дисциплінованістю, культурою поведінки і спілкування, турботою про збереження здоров'я, здоровий спосіб життя тощо.

Приватно-методичні вміння визначаються спроможністю планувати, відбирати, синтезувати навчальний матеріал; розробляти дидактичні матеріали до занять; проводити навчальні та позанавчальні спортивні та фрізкультурно-оздоровчі заходи; організовувати різні форми спортивномасової роботи; залучати дітей та молодь до занять у спортивних секціях та спрямовувати їх на збереження здоров'я, ведення здорового способу життя, вдосконалення фрізичних якостей тощо.

Комунікативно-організаторські вміння передбачають здатність встановлювати педагогічно доцільні взаємини з окремими учнями, групами, колективами; створювати сприятливий мікроклімат; регулювати взаємини студентів у колективі під час занять, на спортивних тренуваннях, змаганнях тощо; відповідно до умов, що змінюються, перебудовувати свою поведінку.

Дослідницькі вміння характеризуються здатністю до цілісного уявлення про науку як систему знань, актуальні проблеми галузі, суть мети, завдань, предмета, об'єкта та методів дослідження; планування й організацію наукового експерименту, його обробки, узагальнення та представлення результатів наукових досліджень тощо.

Проте, за всієї різнобічної наповненості представленої професіограми вона повинна бути побудована 3 урахуванням сучасних вимог до майбутнього фахівця та тенденцій гуманізації української освіти і сфери фрізичної культури і спорту.

Варто зазначити, що для сучасного випускника ЗВО архіважливим $є$ володіння не лише професійними, а й особистісними компетенціями. Так, наприклад, американська телекомунікаційна компанія АТ\&Т розробила програму прогнозування успішності діяльності майбутніх фахівців різних галузей. Використання програми свідчить, що поряд з рівнем розумових здібностей важливого значення у кар'єрному зростанні набувають так звані soft skills («м'які компетенції»), що характеризуються такими якостями, як толерантність, гнучкість, ініціативність, вміння вирішувати конфліктні ситуації, працювати в команді, комунікативні навички тощо. Володіння саме цими компетенціями сприяє підвищенню ефективності праці. Як стверджує відомий експерт Даніель Гоулман, «люди починають розуміти, що для досягнення успіху недо- 
статньо мати лише високий інтелект або технічні знання, необхідно також володіти іншими навичками, які розкривають внутрішні якості, такі як: ініціативність, оптимізм, гнучкість, толерантність. Практика свідчить, що вони цінуються все більше».

Результати понад трьохсот різноманітних досліджень свідчать, що питома вага успіху припадає саме на м'які компетенції порівняно 3 когнітивними якостями. Це стосується усіх без винятку професій і посад, навіть тих, які передбачають найвищий прояв інтелектуальних здібностей. Гоулман стверджує, що володіння високим рівнем інтелектуальних здібностей недостатньо для вченого, щоб досягти вершини кар'єрного росту, необхідно мати вміння слухати, взаємодіяти і переконувати інших, а також внутрішню дисципліну в прагненні до досягнення мети. Зрозуміло, що набір цих якостей буде відрізнятися у представників різних професій. Наприклад, викладач 3 В0 має володіти такими компетенціями: високим рівнем комунікативних навичок, умінням працювати в команді, взаєморозумінням, взаємоповагою, взаємодією тощо [20].

Повертаючись до важливих вимог для побудови профресіограми сучасного фахівця, слід зазначити, що вдосконалення системи освіти та фрізичної культури, їх транссормація як дієві чинники суспільного і професійного становлення майбутнього спеціаліста неможливі поза контекстом гуманістичних цінностей суспільства.

у руслі гуманізації для фрахівців сорери фрізичної культури та спорту має бути притаманним високий рівень культури здорового способу життя та міжособистісної культури спілкування (зокрема, спілкування з особами 3 інвалідністю). Взаємна повага у стосунках між людьми є одним із важливих показників гуманності, що характеризується рядом понять (рис. 4).

3 огляду на зазначене, гуманізація процесу підготовки фрахівців сфери фрізичної культури та спорту полягає у ставленні педагога до студентів як до особистостей зі своїми індивідуальними властивостями, прихильністю, вимогами та системою цінностей. Свої стосунки учасники гуманістично орі-

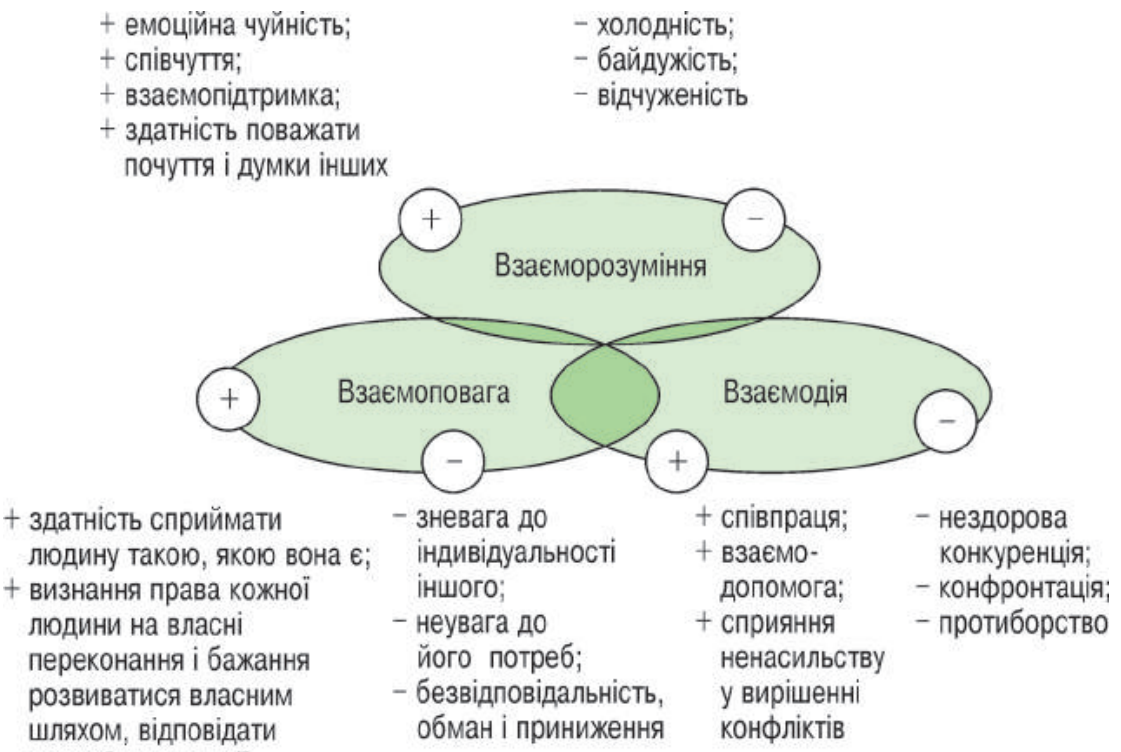

за свої вчинки, дії

Рисунок 4 - Складові гуманності, що визначають характер стосунків між людьми

єнтованого освітнього процесу будують на засадах толерантності та взаємної поваги, коли високий рівень вимог висувається як до себе, так і до підопічних, педагог вірить у здібності своїх студентів, стимулює їх до інтелектуального, фрізичного і моральноетичного вдосконалення, використовуючи гуманістично орієнтовані педагогічні технології.

Однією з першочергових умов, необхідних для гуманізації фізкультурної освіти, є відповідна кваліфікація педагогів. Змістові інваріанти якостей сучасних науково-педагогічних працівників 3В0, зазвичай, включають: емоційну стабільність, емпатію, ділові якості, креативність, організаторські (управлінські) вміння, критичність мислення, професійну компетентність, здатність до самовдосконалення, самоосвіти, саморозвитку тощо.

Сучасна система професійної підготовки повинна бути орієнтована на індивідуальність студента, його творчі інтелектуальні здібності з паралельним удосконаленням змісту освіти та педагогічних технологій, що відображають потреби нових соціальних умов. Головним при цьому $є$ вимога до студента як до творчої, гармонійно розвиненої особистості, здатної вирішувати складні професійні завдання у мінливих соціальних умовах. Це спричиняє необхідність удосконалення змісту профресійної освіти в умо- вах гуманістично орієнтованого процесу фрахової підготовки студентів. При цьому їм потрібні якості, які поки що розцінюються, як тенденції по відношенню до бажаного майбутнього. Водночас у зміст освіти необхідно вкладати критерії оцінки якостей розвитку особистості, а не тільки оцінку засвоєння навчального матеріалу, і не прагнути до звичайного підвищення знань, умінь, компетентностей, коли викладач сприймається лише носієм навчальної інформації, а не організатором творчої роботи.

Формування гуманістично орієнтованого спеціаліста сфери фрізичної культури і спорту передбачає необхідність розвитку мотиваційно-ціннісних орієнтирів, переконань, установок, зацікавленості, вимог, що мають як особистісно, так і соціально значуще гуманістичне підґрунтя. Його спрямованість до фізичної досконалості визначає своєрідну професійну готовність наочно перетворити рухові вміння та навички у гуманістично орієнтовану свідомість майбутнього фахівця.

Серед перешкод у формуванні гуманістично орієнтованих студентів слід виділити об'єктивні, що, в основному, пов'язані з відсутністю належного рівня толерантності відносин у суспільстві в цілому і в установах освіти зокрема, та суб'єктивні, найбільш значущими серед яких $є$ неготовність педагогів ЗВО до проведен- 
ня масштабної роботи з формування морально-етичних норм та цінностей у студентів.

Узагальнення доступної наукової літератури 3 питань системи професійної підготовки, результатів власних досліджень та експертного оцінювання, дає підстави виокремити блоки професіограми спеціаліста сфери фрізичної культури і спорту з урахуванням гуманістичної спрямованості фрахової освіти (рис. 5)

Якості, що наведені в кожному 3 блоків вимог як системи проєктованих властивостей фрахівця, не можуть і не повинні точно відтворюватися в діях кожного випускника, але їх максимальне впровадження у процес виховання і навчання створить передумови для фрормування спеціаліста з високим рівнем розвитку моральноетичних властивостей. Втім, реалізація соціально-гуманістичних засад у процес підготовки спеціаліста ссрери фрізичної культури і спорту сприятиме фрормуванню загальнокультурного кругозору, гуманізації освітнього процесу, розкриттю культурологічної доцільності його педагогічної діяльності, що, в свою чергу, слугуватиме віддзеркаленням професійно ціннісної орієнтації фрахівця, його поглядів, переконань, інтересів, потреб, громадянської позиції, культури здорового способу життя тощо.

Науково-педагогічні працівники повинні виступати головною ланкою якості процесу формування гуманістично орієнтованої особистості, джерелом, і що вкрай важливо, організатором студентів на постійний пошук відповідної інформації про морально-етичні норми та цінності, що сприяють розвитку та духовному збагаченню суспільства. Рівень гуманістичної грамотності та культури науково-педагогічного працівника, впровадження ним інноваційних соціально-гуманістичних технологій в освітній процес мають бути важливими критеріями продуктивності праці фрахівця та підвищення ефективност педагогічного процесу в 3В0.

Гуманізація вищої фрізкультурно освіти покликана створити умови для реалізації спеціалістом своїх кращих якостей, розкриття і розвитку творчого потенціалу особистості, розуміння істинного місця в суспільстві. Гуманізація освітньої діяльності виконує роль механізму виявлення студентом, а іноді і педагогом, свого особистісного інтелектуально-морального потенціалу, формування ціннісного став- лення до нього і потреби максимальної реалізації творчих можливостей.

Отже, увесь комплекс проведених досліджень дозволив на основі визначених педагогічних положень представити дієвий механізм, реалізація якого сприятиме побудові гуманістично орієнтованого освітнього процесу під час підготовки фрахівців сфери фрізичної культури і спорту (рис. 6).

Після з'ясування провідних педагогічних положень гуманізації освітнього процесу наступним кроком наших досліджень стало визначення концептуальних засад гуманістично орієнтованого освітнього процесу під час підготовки фрахівців сфери фізичної культури і спорту на прикладі Національного університету фрізичного виховання та спорту України (НУФВСУ).

Сьогодні навчання у ЗВО не завжди чинить помітний вплив на світогляд, перебудову свідомості студентів, формування їхніх переконань, установок, ціннісних орієнтацій на створення гуманістичного підгрунтя розвитку сучасного суспільства. Зазвичай гуманістично орієнтована особистість формується у процесі виховання в родині, спілкування 3 найближчим оточенням, в освітніх закладах, під впливом засобів масової інформа-

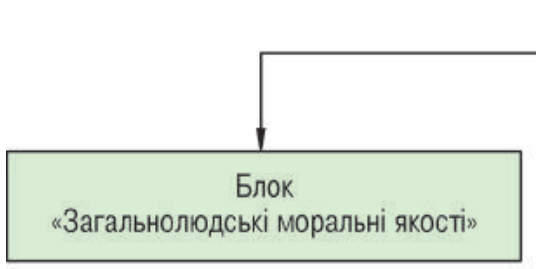

- сталі моральні переконання;

- демократизм у спілкуванні;

- відкритість;

- доброзичливість;

- вміння працювати з людьми;

- увага і довіра до людей:

- моральне здоров'я;

- чесність;

- принциповість;

- вольові якості;

- єдність слова і діла;

- оптимізм;

- свідомість;

- вимогливість до себе;

- інтелектуальний потенціал;

- економічні знання та інформованість;

- культурний кругозір;

- сформованість системи цінностей

\section{Вимоги до спеціаліста}

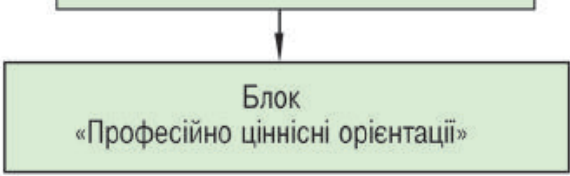

- професійна компетентність;

- творчий підхід;

- самостійність суджень і вчинків;

- опанування новітніх технологій;

- уміння бачити перспективу;

- професійна майстерність;

- потреба в безперервному розширенні та поновленні знань;

- уміння бути вихователем і організатором в колективі

- непримиренність до недоліків, байдужості;

- дисциплінованість;

- пунктуальність;

- організованість;

- терпимість до незвичного;

- гнучкість;

- уміння розподіляти завдання, приймати рішення; вміння забезпечувати економічну ефективність професійної діяльності

Рисунок 5- Блоки професіограми спеціаліста сфери фрізичної культури і спорту з урахуванням гуманістичної спрямованості фахової освіти 
Т а б л и ц я 2. Технологія формування гуманістично орієнтованого фахівця сфери фізичної культури і спорту

\begin{tabular}{|c|c|}
\hline Заходи & Реформування, що відбуваються в межах НУФВСУ \\
\hline $\begin{array}{l}\text { Зміна співвідношення між існуючими } \\
\text { структурами освітнього процесу }\end{array}$ & $\begin{array}{l}\text { Розширення магістратури зі спеціальності «Спорт (професійний та неолімпійський } \\
\text { спорт)» напрямом адаптивний спорт }\end{array}$ \\
\hline $\begin{array}{l}\text { Вдосконалення структури та змісту } \\
\text { професійної підготовки фахівців }\end{array}$ & $\begin{array}{l}\text { • розробка навчально-методичного комплексу з впровадження дисципліни «Адаптивний } \\
\text { спорт» у нормативну частину галузевого стандарту підготовки бакалаврів за напрямом } \\
\text { підготовки «Спорт»; } \\
\text { • формування компетентностей бакалаврів зі спеціальності «Спорт» для роботи зі спор- } \\
\text { тсменами з інвалідністю; } \\
\text { • удосконалення навчально-методичного забезпечення дисципліни «Теорія та методика } \\
\text { тренерської діяльності в обраному виді спорту» шляхом включення модуля «Особливості } \\
\text { підготовки спортсменів з інвалідністю в обраному виді спорту»; } \\
\text { • удосконалення навчально-методичного забезпечення спеціалізованих дисциплін } \\
\text { кафедр медико-біологічних дисциплін, спортивної медицини; фізичної терапії та } \\
\text { ерготерапії; психології і педагогіки шляхом включення модулів з проблем фізкультурно- } \\
\text { спортивної роботи зі спортсменами з інвалідністю }\end{array}$ \\
\hline $\begin{array}{l}\text { Розробка моделі професійно важ- } \\
\text { ливих якостей діяльності гуманіс- } \\
\text { тично орієнтованого фахівця сфери } \\
\text { фізичної культури і спорту }\end{array}$ & $\begin{array}{l}\text { Створення блоків професіограми спеціалістів сфери фізичної культури і спорту з ураху- } \\
\text { ванням гуманістичної спрямованості їхньої фахової освіти }\end{array}$ \\
\hline
\end{tabular}

виховання підростаючого покоління, як завжди, лягає на освітні заклади. Протистояти процесам дегуманізації особистості певною мірою може гуманістично орієнтований освітній процес, що грунтується на високих моральних цінностях і педагогічній майстерності науково-педагогічного працівника ЗВО.

У НУФВСУ накопичено позитивний досвід з формування гуманістичних засад у роботі зі студентами у межах викладання навчальних дисциплін «Адаптивний спорт», «Адаптивне фізичне виховання» та похідних від них. Розробляються гуманістично орієнтовані компоненти змісту освіти студентів III-IV курсів фракультетів здоров'я, фрізичного виховання та туризму; тренерського; спорту і менеджменту, а також магістрантів спеціальності «Спорт» (професійний, неолімпійський та адаптивний спорт). Підготовка студентів здійснюється на основі ідей інтегрованості, варіативності, інноваційності змісту освіти з орієнтацією на гуманістичні цінності.

«Адаптивний спорт» - навчальна дисципліна, яка має потужний гуманістичний потенціал, що передбачає його реалізацію відповідно до вимог сучасного суспільства, орієнтованого на пріоритетність розвитку людства на основі формування свідомого толерантного ставлення до всіх гро- мадян. Ґрунтуючись на моральноетичних засадах, гуманістично орієнтований освітній процес сприяє приборканню негативних почуттів і посиленню позитивних, формуючи гуманістично виправдані стереотипи поведінки майбутніх фрахівців.

у структурі фрахової підготовки студентів НУФВСУ зміст програми навчальної дисципліни «Адаптивний спорт» запрограмований унікальними можливостями гуманістичного впливу на студентів. Основним об'єктом вивчення є особи з інвалідністю, різнопланові можливості яких успішно реалізуються у соціумі внаслідок занять руховою активністю. Грунтуючись на морально-етичних засадах гуманістично орієнтованого освітнього процесу, викладання дисципліни «Адаптивний спорт» забезпечує інтелектуальне підґрунтя у студентів до свідомого толерантного ставлення до всіх громадян, формуючи у них гуманістично виправдані стереотипи поведінки. Корекція стосунків викладача і студента, учасників педагогічного процесу передбачає поважне, гідне та демократичне ставлення один до одного. Початковим методологічним положенням побудови гуманістично орієнтованого освітнього процесу є уявлення про те, що толерантна особистість може формуватися лише у процесі добродійної діяльності.
Результати досліджень дозволяють визначити заходи із формування гуманістично орієнтованого спеціаліста сфери фізичної культури і спорту. Їх впровадження передбачає таке: зміну співвідношення між існуючими структурами управління освітнім процесом 3В0; вдосконалення структури та змісту професійної підготовки фахівця; розробку моделі професійно важливих якостей гуманістично орієнтованого спеціаліста (табл. 2).

у структурі розробленого змісту фрізкультурної освіти НУФВСУ гуманістично орієнтований підхід в освітньому процесі забезпечується за рахунок таких дисциплін: «Адаптивний спорт», «Адаптивне фрізичне виховання», «Соціально-правові основи сучасного спорту», «Основи фрізичної терапії», «Психологія», «Застосування психології в паралімпійському спорті», «Педагогіка», «Анатомія людини», «Фізіологія людини», «Фізіологія рухової активності і спорту», «Спортивна медицина», «Онтокінезіологія людини», «Біомеханіка», «Спортивні споруди та тренажерне обладнання», «/Hформатика та інфрормаційні технології у фізичній культурі і спорті», «Теорія та методика тренерської діяльності в обраному виді спорту» тощо. Велике значення відіграє також практика магістрантів, що проходить у Національному комітеті спорту інвалідів 
України, Українському центрі з фізичної культури і спорту осіб з інвалідність «Інваспорт», спортивних клубах осіб з інвалідністю, а також участь іх як волонтерів у заходах Всеукраїнської громадської організації «Спеціальна Олімпіада України» тощо.

Важливим кроком впровадження гуманістично орієнтованого підхіду в освітньому процесі НУФВСУ є проведення конференцій, наукових, виховних і освітніх заходів із запрошенням фіхівців, які працюють з особами 3 інвалідністю, та безпосередньо самих осіб з інвалідністю (видатних паралімпійців та дефрлімпійців, військовослужбовців, які отримали інвалідність під час бойових дій). Так, у межах XI Міжнародної консреренції «Молодь і олімпійський рух» відбулась секція «Паралімпійський та дефрлімпійський спорт. Спеціальні Олімпіади». У заході брали участь здобувачі вищої освіти освітніх ступенів бакалавр, магістр, доктор фрілософрії та науково-педагогічні працівники НУФВСУ, Львівського державного університету фізичної культури імені Івана Боберського, Придніпровської державної академії фрізичної культури, Харківської державної академії фізичної культури.

у засіданні секції взяла участь Оксана Горбач - координатор Ігор Нескорених в Україні. Її доповідь була присвячена особливостям підготовки та участі національної збірної команди в Invictus Games (міжнародні спортивні змагання для військовослужбовців та ветеранів із обмеженими фрізичними можливостями, набутими під час виконання службових обов'язків), а також про досвід інтеграції військовослужбовців та ветеранів з пораненнями, травмами та ознаками інвалідності засобами спорту.

Юлія Батенкова-Бауман - українська біатлоністка, лижниця, заслужений майстер спорту України, багаразова срібна та бронзова призерка зимових Паралімпійських ігр 2006, 2010, 2014 рр., чемпіонка зимових Паралімпійських ігор 2018 у Пхьончхані - розповіла про те, як прийшла у спорт, мотивацію до занять спортом, відчуття, які виникли під час нагородження золотою медаллю.
Іван Ошаров - єдиний сноубордист у паралімпійській збірній команді України, учасник Паралімпійських ігор 2014, 2018 рр. - розкрив свою життєву історію втрати кінцівки, перемоги над недугою та історії занять сноубордингом.

Гості відповіли на запитання студентської та наукової спільноти, надихнули на соціальні ініціативи, важливість танеобхідність отримання якісних професійних знань майбутніх тренерів, психологів, реабілітологів для соціальної інтеграції та інклюзії людей з інвалідністю засобами спорту. Подібні заходи позитивно впливають на формування гуманістичного світогляду як здобувачів освіти, так і наукових та науково-педагогічних працівників.

Наступним кроком наших досліджень стало окреслення концептуальних положень моделі реалізації гуманістично орієнтованих засад в освітньому процесі під час підготовки фрахівців ссрери фізичної культури і спорту на основі її опрацювання у процесі підготовки спеціалістів у НУФВСУ (рис. 7).

У ході досліджень визначено критерії ефрективності навчання за гуманістичного підходу, що мають свої особливості. Ефективність педагогічної діяльності не зводиться лише до оцінки знань, що визначаються за кінцевим результатом засвоєння: рівнем відтворення знань, застосуванням знань за зразком, застосування знань і навичок у нестандартних ситуаціях. Оцінюється не лише обсяг знань і ступінь інсрормованості студентів, а й те, як вони узгоджуються із внутрішніми психічними змінами, що відбулися під час навчання і посприяли формуванню комплексу морально-етичних якостей.

3 урахуванням зазначеного, розробляється система навчальних завдань, проміжного контролю 3 метою корекції знань, підсумкового контролю у міру опрацювання матеріалу. Для ЗВ0 гуманістичне підгрунтя освіти визначається розробкою змісту та пошуком адекватних технологій, реалізація яких передбачає необхідність опрацювання та впровадження сучасних інтерактивних методів навчання, зокрема, таких як дебати, тренінги, рольові ігри, мозковий штурм, ситуаційні завдання, кейси тощо.

Представлені положення з гуманізації освітнього процесу під час підготовки фрахівців сфрери фізичної культури і спорту відтворюють єдину цілісну структуру (конгломерат), де кожен 3 ії компонентів як самостійно, так і в сукупності спрямовані на досягнення загальної мети - формування фахівця з високим рівнем розвитку інтелектуально-морального потенціалу.

\section{Висновки:}

1. Підготовка спеціалістів ссрери фрізична культура і спорт має передбачати переорієнтацію їх фрахової освіти зі спрямування переважно на вирішення завдань тренувальної спрямованості занять на формування культури майбутнього фахівця, створюючи умови для гуманізації освітнього процесу шляхом розробки механізму побудови гуманістично орієнтованого освітнього процесу в ЗВО. Зазначені заходи сприятимуть тому, що фрізична культура стане елементом способу життя людей, увійде в їхній побут невід'ємною частиною загальної культури, а її носій - фрахівець з фізичної культури та спорту - регулюватиме іiі спрямованість, засоби, результати тощо $з$ урахуванням ії загальнокультурної і загальноосвітньої цінності.

2. У результаті впровадження розробленої технології формування гуманістично орієнтованого фрахівця сфрери фрізичної культури і спорту та імплементації її основних положень в освітній процес НУФВСУ відбулися зміни у структурі та змісті професійної підготовки студентів на основі розробки навчально-методичного комплексу 3 впровадження дисципліни «Адаптивний спорт»: у нормативній частині галузевого стандарту підготовки бакалаврів за напрямом підготовки «Спорт»; під час формування компетентностей бакалаврів зі спеціальності «Спорт» для роботи зі спортсменами 3 інвалідністю; вдосконалене навчально-методичне забезпечення дисциплін спортивно-педагогічних кафредр та спеціальних дисциплін теоретичних кафедр шляхом включення модулів з питань фрізкультурноспортивної роботи зі спортсменами 3 інвалідністю. Впроваджені структур- 


\begin{tabular}{|c|c|c|c|c|}
\hline Мета & \multicolumn{4}{|c|}{ Формування готовності фахівців сфери фізичної культури і спорту до гуманістично орієнтованої діяльності } \\
\hline \multirow{2}{*}{$\begin{array}{c}\text { Зміст } \\
\text { дисциплін } \\
\text { на кафедрах }\end{array}$} & $\begin{array}{c}\text { Спеціалізовані кафедри } \\
\text { (на прикладі адаптивного спорту) }\end{array}$ & Теоретичні кафедри & $\begin{array}{c}\text { Спортивно- } \\
\text { педагогічні кафедри }\end{array}$ & Практика \\
\hline & $\begin{array}{l}\text { Змістові модулі: } \\
\text { 1. Соціальні, організаційні та } \\
\text { педагогічні аспекти функціону- } \\
\text { вання адаптивного спорту. } \\
\text { 2.Виникнення та розвиток } \\
\text { основних напрямів адаптивного } \\
\text { спорту у світі та в Україні. } \\
\text { 3.Теоретико-методичні основи } \\
\text { підготовки спортсменів } \\
\text { в адаптивному спорті. } \\
\text { 4.Сучасні тенденції, проблеми } \\
\text { та перспективи розвитку } \\
\text { адаптивного спорту }\end{array}$ & $\begin{array}{l}\text { Включення модулів } \\
\text { з проблем фізкультурно- } \\
\text { спортивної роботи } \\
\text { зі спортсменами } \\
\text { з інвалідністю } \\
\text { у навчальний матеріал } \\
\text { дисциплін кафедр } \\
\text { медико-біологічних } \\
\text { дисциплін, спортивної } \\
\text { медицини; фізичної } \\
\text { терапії та ерготерапії; } \\
\text { психології та педагогіки }\end{array}$ & $\begin{array}{l}\text { Включення модуля } \\
\text { "Особливості } \\
\text { підготовки спортсменів } \\
\text { з інвалідністю } \\
\text { в обраному виді } \\
\text { спорту» в дисципліну } \\
\text { «Теорія та методика } \\
\text { тренерської діяльності } \\
\text { в обраному виді спорту» }\end{array}$ & $\begin{array}{l}\text { Як об'єкти практики } \\
\text { використовувати } \\
\text { спортивні організації, } \\
\text { що працюють } \\
\text { з особами з інвалід- } \\
\text { ністю, та забезпечу- } \\
\text { вати впровадження } \\
\text { волонтерської } \\
\text { діяльності }\end{array}$ \\
\hline $\begin{array}{l}\text { Педагогічні } \\
\text { умови }\end{array}$ & $\begin{array}{l}\text { Зміна співвідношення між } \\
\text { існуючими структурами } \\
\text { освітнього процесу }\end{array}$ & $\begin{array}{l}\text { рекція структури та змісту } \\
\text { офесійної підготовки } \\
\text { ахівців }\end{array}$ & \multicolumn{2}{|c|}{$\begin{array}{l}\text { Розробка моделі професійно важливих } \\
\text { якостей гуманістично орієнтованої особистості } \\
\text { фахівця сфери фізичноі культури і спорту }\end{array}$} \\
\hline $\begin{array}{l}\text { Складові } \\
\text { підготовки }\end{array}$ & $\begin{array}{l}\text { - інформаційна; } \\
\text { - адаптивна; }\end{array}$ & \multicolumn{2}{|c|}{$\begin{array}{l}\text { - соціальна; } \\
\text { - комунікативна; }\end{array}$} & $\begin{array}{l}\text { емоційна; } \\
\text { діяльнісна }\end{array}$ \\
\hline Результат & \multicolumn{4}{|c|}{$\begin{array}{l}\text { Сукупність знань, морально-етичних навичок поведінки та спрямованість на їх реалізацію у процесі тренувальних } \\
\text { занять, змагань та інших видів суспільно-корисної діяльності фахівців сфери фізичної культури і спорту }\end{array}$} \\
\hline
\end{tabular}

Рисунок 7- Модель реалізації гуманістично орієнтованих засад в освітньому процесі під час підготовки фрахівців сфрери фрізичної культури і спорту

ні перетворення забезпечують підвищення рівня професійної підготовки спеціалістів шляхом формування знань, умінь, навичок, компетентностей; соціально-гуманістичних цінностей, духовно-морального, інтелектуального розвитку; професійно значущих рис особистості, необхідних для успішного вирішення завдань ссери фрізичної культури і спорту.

3. Навчальна дисципліна «Адаптивний спорт» у структурі фахової підготовки фрахівців НУФВСУ створює унікальні можливості гуманістичного впливу на студентів у зв'язку з особливостями свого змісту. Основним об'єктом вивчення є особи з інвалідністю та їхні різнопланові можливості, що реалізуються у соціумі внаслідок занять руховою активністю. Ґрунтуючись на морально-етичних засадах гуманістично орієнтованого освітнього процесу, викладання дисципліни «Адаптивний спорт» забезпечує створення інтелектуального підґрунтя у студентів для свідомого толерантного ставлення до всіх громадян, фрормує гуманістично виправдані стереотипи їх поведінки.

Зміна акценту в стосунках на визнання вмінь, а не зосередженість на інвалідності, беззаперечно сприятиме можливості об'єднання різних прошарків суспільства через нові шляхи взаємодії, що у результаті забезпечить фрормування основи для інтеграційних процесів і беззаперечно впливатиме на підвищення рівня гуманізації суспільства.

Отже, представлені концептуальні положення реалізації соціальногуманістичних засад адаптивної фрізичної культури в українському освітньому просторі стануть запорукою не лише формування фрахівця 3 високим рівнем розвитку інтелектуальноморального потенціалу, а й сприятимуть гуманізації соціуму в цілому.

Перспективи подальших досліджень полягають у розробці напрямів удосконалення освіти й фрізичної культури і спорту, що дозволить підвищити їх роль у вирішенні проблем соціальноекономічного зростання країни, наповнити проведені перетворення гуманістичним змістом та створити основу для їх подальшого розвитку.

Конфлікт інтересів. Автори заявляють, що відсутній будь-який конфрлікт інтересів.

\section{ЛITEPATУPA}

1. Альошина Al. Профрілактика й корекція фрункціональних порушень опорно-рухового апарату дошкільнят, школярів та студентської молоді у процесі фрізичного виховання: монографія. Луцьк; 2015. 356 с.

2. Амонашвили ША. Размышления о гуманной педагогике. Издат. дом Шалвы Амонашвили; 1996.496 с.

3. Борисова ОВ, Когут І0, Маринич ВЛ. Особливості підготовки майбутніх фахівців сфери фрізичної культури та спорту для роботи з особами з інвалідністю. Фізична культура і спорт: досвід та перспективи: матеріали міжнародної науково-практичної конференції. Чернівці: Чернівецький нац. ун-т; 2017. с. 122-124.

4. Брискин ЮА, Евсеев СП, Передерий АВ. Адаптивный спорт. Москва: Сов. Спорт; 2010. 316 c.

5. Бріскін Ю, Передерій А. Спорт інвалідів як складова профільної освіти за напрямом 
«Спорт». Теорія і методика фрізичного виховання і спорту. 2009;2:3-11.

6. Верещагин ВВ. Профессиограмма учителя фиизической культуры [Інтернет]. 2016 [цитовано 2020 Лип 15] Доступно: https:// www.google.com.ua/webhp?sourceid=chromeinstant\&ion

7. Дутчак МВ. Протиріччя та особливості гуманізації фізичного виховання та спорту. Спортивна наука України. [Інтернет]. 2008 [цитовано 2020 Трав 15]; 4(19):12-26. Доступно http://www.sportscience.org.ua/index.php/Arhiv. html.

8. Евсеев СП, Евсеева ОЭ. Технологии физкультурно-спортивной деятельности в адаптивной физической культуре. Москва: Советский спорт; 2013. 388 с

9. Зубченко ЛВ. Гуманістичні засади оптимізації процесу фрізичного виховання студентів. Правовий часопис Донбасу. 2018;2(63): 164-168.

10. Імас $€$, Борисова О, Когут І. Особливост змісту професійної підготовки фахівців сфери фізичної культури та спорту щодо роботи з особами з інвалідністю. Фізичне виховання, спорт і культура здоров'я у сучасному суспільстві: зб. наук. пр. Східноєвроп. нац. ун-ту ім. Лесі Українки. 2016;3 (35):17-25.

11. Когут IO. Гуманізація освіти та сус пільства як передумова формування теорі адаптивної фізичної культури. Теорія і методика фрізичного виховання і спорту. 2014;1:32-36.

12. Когут I, Маринич В, Чебанова К. Загальні положення інклюзивної освіти як сучасного соціально-педагогічного феномену та підгрунтя для соціальної інтеграції спортсменів з інвалідністю. Теорія і методика фрізичного виховання. 2017;2:4-19.

13. Круцевич ТЮ, редактор. Теорія і методика фізичного виховання: підручник для студентів ВН3 фізичного виховання і спорту. Київ: Олімпійська література; 2017. Т. 1.

14. Круцевич ТЮ, редактор. Теорія і методика фізичного виховання: підручник для студентів ВНЗ фрізичного виховання і спорту. Київ: Олімпійська література; 2017. Т. 2.

15. Кряж ВН, Кряж ЗС. Гуманизация фризического воспитания. Минск: НИО; 2001. 179 с.

16. Литвиненко ОМ. Формування гуманістичних цінностей у майбутніх учителів фізичного виховання. Вісник Луганського національного університету імені Тараса Шевченка. Педагогічні науки. 2013;112:169-173.

17. Маринич ВЛ, Когут ІО. Аналіз інноваційних підходів організації фрізкультурнооздоровчої роботи в закладах освіти. Спортивний вісник Придніпров'я. 2013;1:28-35.

18. Передерий АВ, Брискин ЮА. Практи ческая составляющая подготовки кадров для инваспорта. Sport Olimpic şi sportul pentru toţi: Materialele Congresului Şt. Intern. - Ch. : USEFS 2011;2:103-108.

19. Сманцер АП, Рангелова ЕМ. Гуманизация и демократизация педагогического процесса в условиях университетского образования. Минск: БГУ. [Інтернет]. 2011. [цитовано 2020 Трав 11] Доступно: https://elibrary.ru/item. asp? id=18089343

20. Центр оценивания и развития компе тенций в УАГИ ВМУУ : [Інтернет]. 2016 [цитовано 2020 Трав 15] Доступно: http://ru.osvita.ua/ vnz/high_school/44249/

21. Шиян БМ, Гуменюк СВ. Гуманізація процесу фізичного виховання школярів. Фізичне виховання в школі. 2009;3:40-46.
22. Kogut I, Marynych V. Organization maintenance of health related physical culture work with students in out-of-school establishments. Physical Education of Students. 2016;4:12-23.

\section{LITERATURE}

1. Alyoshyna Al. Prevention and correction of functional disorders of the musculoskeletal system of preschool children, schoolchildren and student in the process of physical education: monograph. Lutsk; 2015. 356 p.

2. Amonashvili SA. Reflections on humane pedagogy. Izdat. dom Shalva Amonashvili; 1996. $496 \mathrm{p}$.

3. Borisova OV, Kohut IO, Marynych VL. Features of training future specialists in the field of physical culture and sports to work with disabled people. Physical culture and sport: experience and prospects: materialy mizhnarodnoi naukovo-praktychnoi konferentsii. Chernivtsi; 2017. p. 122-124.

4. Briskin YA, Evseev SP, Perederiy AV. Adaptive sport. Moscow: Sov. Sport; 2010. 316 p.

5. Briskin Y, Perederii A. Sport for the disabled as a component of specialized education in the field of «Sport». Teoriia i metodyka fizvykhovannia i sportu. 2009:2:3-11.

6. Vereshchagin BB. Professiogram of a physical education teacher [Internet]. 2016 [cited 2020 Jul 15] Available: https://www.google.com ua/webhp?sourceid=chrome-instant\&ion

7. Dutchak MV. Contradictions and features of humanization of physical education and sports. Sports science of Ukraine. [Internet]. 2008 [cited 2020 May 15]; 4 (19): 12-26. Available: http:// www.sportscience.org.ua/index.php/Arhiv.html.

8. Evseev SP, Evseeva OE. Technologies of physical culture and sports activities in adaptive physical culture. Moscow: Sov. Sport; 2013. 388 p.

9. Zubchenko LV. Humanistic principles of optimizing the process of physical educa tion of students. Pravovyi chasopys Donbasu 2018;2(63):164-168.

10. Imas Y, Borysova 0, Kohut I. Peculiarities of the content of professional training of specialist in the field of physical culture and sports on work with persons with disabilities. Physical education, sports and health culture in modern society: zb. Naukovykh prats Skhidnoievropeyskoho nats Universytetu im. Lesi Ukrainjy. 2016;3 (35):17-25

\section{ІНФОРМАЦЯ ПРО АВТОРІВ}

Когут Ірина Олександрівна https:orcid.org/0000-0002-8862-9545, kogut_irina@ukr.net Гончаренко Євген Володимирович https://orcid.org/0000-0002-7196-3061, e-mail vespo. vaulter@gmail.com

Матвєєв Сергій Федорович e-mail vespo.vaulter@gmail.com, https://orcid.org/0000-0002 5998-8020

Маринич Вікторія Леонідівна https:orcid.org/0000-0003-2784-680X, wikleon@ukr.net

Національний університет фізичного виховання і спорту України,

03150, Київ, вул. Фізкультури, 1.

\section{INFORMATION ABOUT THE AUTHORS}

Kogut Iryna https:orcid.org/0000-0002-8862-9545, kogut_irina@ukr.net

Goncharenko levgen https://orcid.org/0000-0002-7196-3061, e-mail vespo.vaulter@gmail.com Matvieiev Serhii e-mail vespo.vaulter@gmail.com, https://orcid.org/0000-0002-5998-8020 Marynych Viktoriia https:orcid.org/0000-0003-2784-680X,wikleon@ukr.net

National University of Ukraine on Physical Education and Sport,

03150, Kyiv, Fizkul'tury str., 1. 